\title{
Laboratory demonstration of a prozone-like effect in HRP2-detecting malaria rapid diagnostic tests: implications for clinical management
}

\author{
Jennifer Luchavez ${ }^{1}$, Joanne Baker ${ }^{2}$, Sheila Alcantara', Vicente Belizario $\mathrm{Jr}^{3}$, Qin Cheng ${ }^{2}$, James S McCarthy ${ }^{4}$ and \\ David Bell| ${ }^{*^{*}}$
}

\begin{abstract}
Background: Malaria rapid diagnostic tests (RDTs) are now widely used for prompt on-site diagnosis in remote endemic areas where reliable microscopy is absent. Aberrant results, whereby negative test results occur at high parasite densities, have been variously reported for over a decade and have led to questions regarding the reliability of the tests in clinical use.
\end{abstract}

Methods: In the first trial, serial dilutions of recombinant HRP2 antigen were tested on an HRP2-detectiing RDT. In a second trial, serial dilutions of culture-derived Plasmodium falciparum parasites were tested against three HRP2detecting RDTs.

Results: A prozone-like effect occurred in RDTs at a high concentration of the target antigen, histidine-rich protein2 (above 15,000 $\mathrm{ng} / \mathrm{ml}$ ), a level that corresponds to more than 312000 parasites per $\mu \mathrm{L}$. Similar results were noted on three RDT products using dilutions of cultured parasites up to a parasite density of $25 \%$. While reduced line intensity was observed, no false negative results occurred.

Conclusions: These results suggest that false-negative malaria RDT results will rarely occur due to a prozone-like effect in high-density infections, and other causes are more likely. However, RDT line intensity is poorly indicative of parasite density in high-density infections and RDTs should, therefore, not be considered quantitative. Immediate management of suspected severe malaria should rely on clinical assessment or microscopy. Evaluation against high concentrations of antigen should be considered in malaria RDT product development and lot-release testing, to ensure that very weak or false negative results will not occur at antigen concentrations that might be seen clinically.

\section{Background}

Rapid and accurate diagnosis is key to effective treatment and management of malaria [1]. The wide use of lateral flow rapid diagnostic tests (RDT) is essential to achieve this, as microscopy is impractical in many areas. The safety and credibility of many diagnostic programmes relies therefore on the accuracy of RDTs. While some RDTs have long proven effective in field and laboratory studies and more recently in wide-scale routine use [2-8], false negative results, in particular,

\footnotetext{
* Correspondence: david.bell@finddiagnostics.org

${ }^{5}$ Foundation for Innovative New Diagnostics (FIND), Geneva, Switzerland; formerly World Health Organization - Regional Office for the Western Pacific, Manila, The Philippines

Full list of author information is available at the end of the article
}

have potential for harming patient health and damaging the credibility of malaria control programmes. Failure to detect a case of malaria parasitaemia could lead a clinician to withhold potentially life-saving anti-malarial therapy that would have been dispensed if non-specific symptom-based diagnosis had been used.

As is the case for all lateral flow immunochromatographic diagnostic tests, malaria RDTs have limitations due to their reliance on specific antigen-antibody interactions that can be subject to a range of interfering factors, and due to other device-related failures and operator errors. While these devices detect parasite antigen in host blood rather than actual malaria parasites, a semi-quantitative relationship between parasitaemia and 
intensity of the positive result has been reported in some studies [9-12]. However, many factors may affect the relationship between parasite density and antigen concentration, and detection of antigen by the lateral flow device. In addition to variable sensitivity at low parasite density $[4,9,13-15]$, there have long been reports of unexplained negative results at high parasite density [11,16-20]. Possible explanations of these reports have included gene deletions [21], variation in antigen structure [22,23], or a prozone-like effect [24-26].

The prozone phenomenon (high dose hook effect) is a well-recognized phenomenon in a range of immunologic assays depending on antigen-antibody interactions, including rapid antibody-detecting immunological diagnostic tests. They occur when high antibody concentration saturates antigen and prevents lattice formation and precipitation [27-31]. Similar prozone-like effects are observed with antigen assays for a number of applications [32-35], and observed in certain malaria tests [24].

A prozone-like effect occurring with malaria RDTs in patients who have very high parasite density could lead to inappropriate withholding of antimalarial treatment to patients who require urgent therapy, with an isolated case recently being reported [24]. This paper reports an investigation of the potential of a prozone-like effect to cause false negative RDT results. The effect of adding varying amounts of recombinant HRP-2 (rHRP-2) to a commercially-available malaria RDT designed to detect this common target antigen was observed, and the study repeated using high-density culture-derived Plasmodium falciparum parasites.

\section{Methods}

The study was performed in two parts; Trial 1 using recombinant HRP2 in the Research Institute for Tropical Medicine, the Philippines, in 2004, and Trial 2 using cultured $P$. falciparum in the Army Malaria Institute (AMI), Australia in 2009.

\section{Trial 1}

\section{Preparation of antigen dilutions}

To assess the effect on the RDT of very high antigen concentration, recombinant HRP-2 (National Bioproducts Institute [Dr Martin Bubb], Pinetown, South Africa) was serially diluted from an initial concentration of $1.5 \mathrm{mg} / \mathrm{mL}$ with parasite-negative type "O" blood down to $1: 100,000$, with resultant antigen concentrations ranging from $1,500,000 \mathrm{ng} / \mathrm{mL}$ to $15 \mathrm{ng} / \mathrm{mL}$.

To determine equivalent parasite densities to the recombinant antigen used, the value of $9.6 \mathrm{ng} / \mathrm{mL}$ at 200 parasite $/ \mu \mathrm{L}$ is used, based on the median value of 79 infected patients diluted to 200 parasites $/ \mu \mathrm{L}$ reported for the evaluation panel used in the first round of the WHO product testing programme $[36,37]$. An ELISA method had been used to determine these concentrations, as detailed in version 1 of the Methods Manual for the WHO product testing programme [38]. This indicates an equivalent parasite density range of $31 \times 10^{6}$ (biologically implausible) to 313 parasites $/ \mu \mathrm{L}$ (Table 1 ).

\section{RDTs}

The serially diluted antigen preparations were tested on a HRP-2 detecting RDT, Paracheck Pf (Orchid Biomedical Systems, India; Lot Number 31083A; Expiry 04/ 2005), which had been stored at $4^{\circ} \mathrm{C}$. The RDT was prepared according to the manufacturer's instructions, with micropipettes used to ensure exactly $5 \mu \mathrm{L}$ of blood from each antigen dilution was pipetted onto the sample well. Six drops of buffer were added to the buffer well immediately. After 15 minutes, the results were read visually by three experienced technicians, comparing the colour intensity of the test band against a standard RDT rating chart developed previously by WHO and RITM, rated from 0 (no band or negative), 1 (very faint) to 4 (strong line) [39]. The average of the three blinded readings was recorded for each test. The intensity of each test band was measured in parallel using a densitometer designed for lateral flow tests ('Videolab', Protea-Synteco, Moscow, Russia).

\section{Trial 2}

\section{Cultured $P$. falciparum parasites}

Five culture-adapted $P$. falciparum lines originating from different geographic areas (GA3, FCR3, SJ44, S55 and 7G8) were cultured in vitro, as previously described [22]. Parasite cultures were repeatedly synchronized using 5\% sorbitol [40], and harvested when parasitaemia reached $\geq 10 \%$, with a majority of parasites at ring stage. The percentage parasitaemia at which parasite lines SJ44, S55, FCR3, 7 G8 and GA3 were harvested were $10 \%, 16 \%, 16 \%, 16 \%$ and $17 \%$, respectively. A separate culture of $7 \mathrm{G} 8$ was harvested at a parasitaemia of $25 \%$.

\section{Dilutions of the parasites}

An aliquot of each harvested parasite (3\% haematocrit) was serially diluted 10 fold five times using normal red blood cells at $3 \%$ haematocrit. An aliquot of the undiluted parasite and each dilution was tested on RDTs. To imitate the conditions of patient blood, another aliquot of the harvested parasites was first concentrated to 50\% haematocrit, then serially diluted 10 fold five times using normal human blood at $50 \%$ haematocrit. Aliquots of the undiluted blood and each of the dilutions were also tested on RDTs. It should be noted that an undiluted culture with $10 \%$ parasitaemia at $3 \%$ and $50 \%$ haematocrit would have $\sim 30000$ and $\sim 500000$ parasites $/ \mu \mathrm{L}$, respectively.

\section{Performing rapid diagnostic tests}

Three RDTs for malaria were used to test serial dilutions of the cultured parasites: ICT Malaria Combo 
Table 1 Recombinant HRP2 concentrations used in Trial 1, and equivalent parasite densities derived from the median HRP2 concentration of dilutions of 200 parasite/ $\mu \mathrm{L}$ of the WHO global specimen bank

\begin{tabular}{llll}
\hline $\begin{array}{l}\text { HRP2 concentration } \\
(\mathbf{n g} / \mathbf{m L})\end{array}$ & Line intensity (densitometer) & $\begin{array}{l}\text { Mean line intensity } \\
\text { ( } \text { readers) }\end{array}$ & $\begin{array}{l}\text { Calculated parasite density equivalent } \\
\text { (parasite/ } \mathbf{\mu L})\end{array}$ \\
\hline 15 & 1.8 & 1.3 & 313 \\
150 & 7.2 & 3.0 & 3,125 \\
1,500 & 16.9 & 4.0 & 31,250 \\
15,000 & 17.9 & 4.0 & 312,500 \\
150,000 & 13.0 & 3.7 & $3,125,000$ \\
300,000 & 10.8 & 3.0 & $6,250,000$ \\
500,000 & 5.2 & 2.3 & $10,416,667$ \\
750,000 & 4.4 & 2.0 & $15,625,000$ \\
$1,000,000$ & 2.4 & 2.0 & $20,833,333$ \\
$1,500,000$ & 1.5 & 1.0 & $31,250,000$ \\
\hline
\end{tabular}

Cassette Test (ML02, ICT Diagnostics, South Africa), First Response Malaria Antigen pLDH/PfHRP2 Combo (Cat. No. 116FRC30, Premier Medical Corporation, India) and SD Malaria Antigen P.f (05FK50, Standard Diagnostics, Korea). All three tests detect $P$. falciparum using antibodies against PfHRP2. The tests were performed according to the manufacturer's instructions. The results were read by two independent readers and recorded as levels 0-4 based on the test band intensity following the same WHO colour reference chart [39].

\section{Ethics approval}

The recombinant antigen challenge study was approved by the Ethics Review Board of the Research Institute for Tropical Medicine, Philippines. Trial 2, using cultured parasites, was approved under the Australian Defence Human Research Ethics Committee approval number 377-05.

\section{Results}

Trial 1

Both visual and densitometer readings showed an overall non-linear relationship with HRP2 concentration and calculated equivalent parasite density (Figure 1). The mean visual intensity of the test band increased rapidly from 1 (faint) at $1.5 \mathrm{mg} / \mathrm{mL}$ to 4 (strong band) at 1,500 $\mathrm{mg} / \mathrm{mL}$ of HRP2, but dropped to only 1.3 as the antigen concentration reached maximum $(1,500,000 \mathrm{ng} / \mathrm{mL}$ or $1.5 \mathrm{mg} / \mathrm{mL}$ ). Densitometer readings showed a trend similar to the visual readings, with the greatest colour intensity of the test band using either method observed between rHRP-2 concentrations of 1,500 - 150,000 ng/ $\mathrm{mL}$ (Figure 1). While the intensity of the test band markedly decreased below the peak intensity at antigen concentrations above this level, the bands remained visible.

Assuming that the relationship between parasite density and antigen concentration remains constant across parasite densities, the parasite density equivalent to the
HRP2 concentration at which line intensity declined $(15,000 \mathrm{ng} / \mathrm{mL})$ corresponds to $>312,500$ parasite $/ \mu \mathrm{L}$.

\section{Trial 2}

Irrespective of the starting parasite density (measured as percent of red cells), testing of all undiluted parasite samples returned a positive result in all 3 RDTs tested. At parasite densities of $10-16 \%$, the undiluted sample gave the highest test band intensity, with some diminution at lower densities. At parasite densities exceeding $17-25 \%$ however, the test bands in the undiluted samples was thinner and qualitatively of reduced intensity compared to the results seen at the first dilution, an observation that remained constant irrespective of the haematocrit of the sample (Table 2), i.e. the peak band intensity was observed in the $1^{\text {st }}$ dilution. The band intensity decreased after the $3^{\text {rd }}$ dilution.

\section{Discussion}

A false negative RDT result, or a failure to appreciate the severity of $P$. falciparum infection, may have lifethreatening consequences for a sick individual denied appropriate treatment. In this study, a marked reduction in intensity of RDT test lines was observed at high antigen concentration, consistent with a prozone-like effect. Importantly however, the test band did not totally disappear up to the highest antigen level or parasitaemia tested $(1.5 \mathrm{mg} / \mathrm{mL}$ and $\sim 500,000$ parasites/ $\mu \mathrm{L}$ respectively). The optimum range of HRP-2 concentrations in terms of line intensity was $\sim 1,500$ to $15,000 \mathrm{ng} / \mathrm{mL}$ (equivalent to $\sim 31,250$ and $\sim 312,500$ parasites $/ \mu \mathrm{L}$ respectively). The results confirm a roughly linear trend in the relationship between line intensity and antigen concentration below that level, thus supporting previous observations of the semi-quantitative properties of RDTs at lower parasite densities, a relationship that disappears at higher densities. At antigen concentration above this range, i.e. $150,000 \mathrm{ng} / \mathrm{mL}$, where the test band intensity 


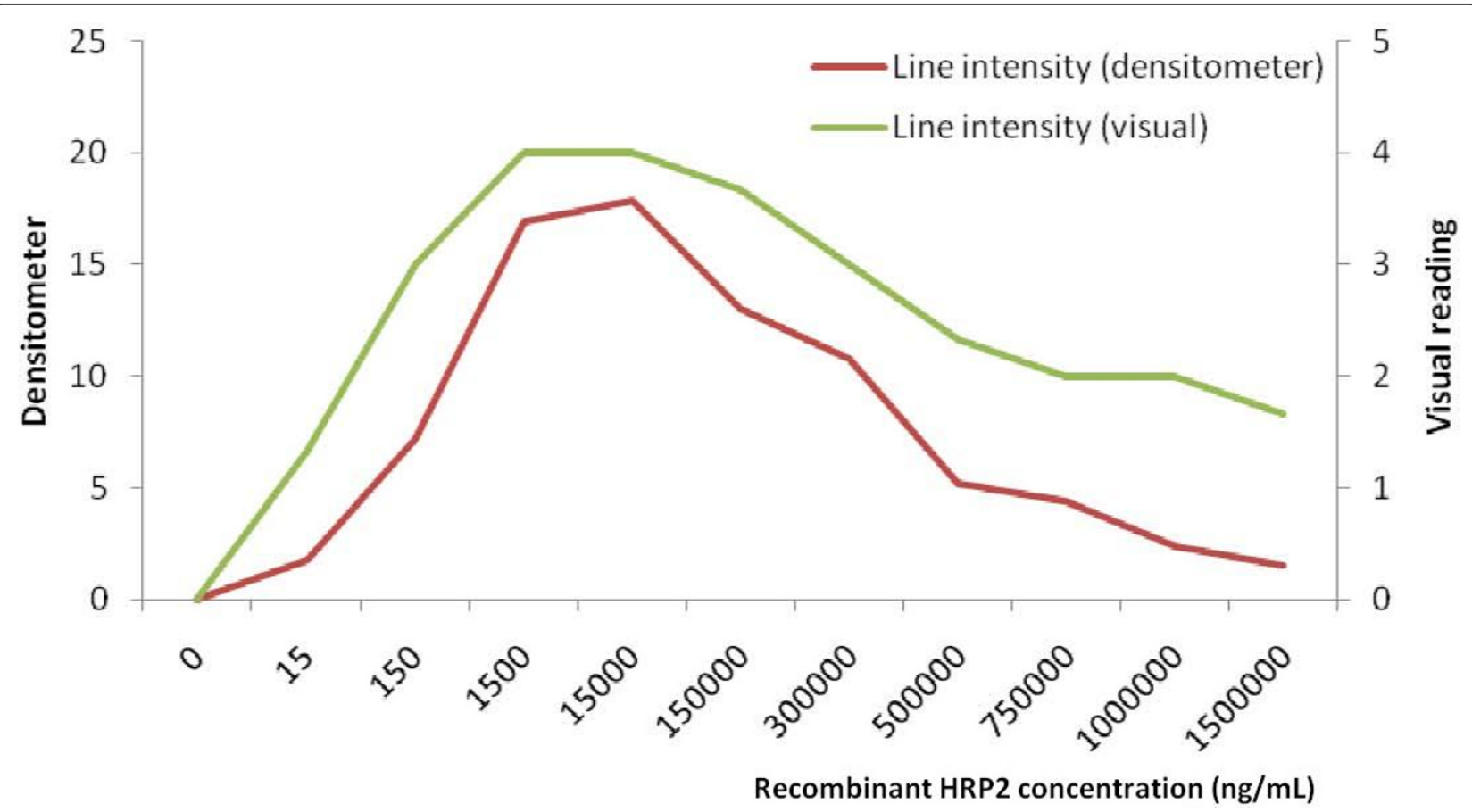

Figure 1 RDT line intensity measured by densitometer and visual rating chart at various dilutions of recombinant HRP2. Note that $x-$ axis scale is arbitrary.

in Trial 1 started to plateau, the expected parasite density (Table 1) would be around 3.1 million parasites per $\mu \mathrm{L}$ of blood, a biologically implausible level. However, antigen concentration varies widely with peripheral parasite density. The range of antigen concentration in the 200 parasite $/ \mu \mathrm{L}$ WHO panel is very wide, ranging from $73.7 \mathrm{ng} / \mathrm{mL}$ to $0.8 \mathrm{ng} / \mathrm{mL}$ after outliers were excluded [36]. Taking the higher value, the antigen concentration at which test line declined may occasionally occur at with a parasite density as low as 170,000 parasites $/ \mu \mathrm{L}$, which is within the range seen clinically in some cases of severe malaria. Therefore, while the line did not disappear at this level providing a false-negative result, a faint line occurring could mislead a clinician to overlooking hyperparasitaemia.

The results of Trial 2 using cultured parasites are broadly consistent with the findings using recombinant protein: at maximum parasite densities ranging from $10 \%$ at $50 \%$ haematocrit to $25 \%$ at $50 \%$ haematocrit ( 500,000 to 1.25 million parasites $/ \mu \mathrm{L}$ ), the intensity of lines did not diminish with any of the six different laboratory strains or with any of the three different RDTs used. However, some 'thinning' of lines indicated that a prozone-like effect may have been beginning to impact the results at higher parasite densities.

Gillet et al reported a prozone-like effect in a number of HRP2-detecting tests at parasitaemias ranging from
$5.5 \%$ to $35 \%$. These consisted of reduced line intensities at maximum concentration that resolved after dilution. Although some line intensities were reported as faint at high parasite densities, in only a single case ( 1 of 16 RDT brands at $11.5 \%$ ) did this result in a test reading negative [24].

The mechanism underlying the prozone-like effect is not well defined for antigen-detecting tests. One plausible explanation is that excess antigen remains unbound after saturation of the signal monoclonal antibody (Mab), and passes up the strip to bind the capture Mab on the RDT test line. If this target antigen reaches the test line in sufficient quantities, it could saturate the capture antibody, thereby preventing the signal Mabantigen complex from binding and accumulating into a visible band. The likelihood of a false negative result at high concentration would therefore depend not only on target antigen concentration (which may vary widely with parasite density), but also on whether too little capture antibody is present in the test line of the RDT.

The demonstration here of a weak prozone-like effect at a very high antigen concentrations and parasite densities in HRP2-detecting RDTs is consistent with previous observations. Importantly no false negative results were observed, and indeed previous observations also suggest that this is rare. However, a combined effect whereby the non-linear relationship between antigen 
Table 2 Detection results of dilutions of cultured parasites on three brands of RDTs in Trial 2

\begin{tabular}{|c|c|c|c|c|c|c|c|}
\hline \multirow[t]{2}{*}{ Line \& Origin } & \multirow{2}{*}{$\begin{array}{l}\text { Parasitaemia } \\
\%\end{array}$} & \multicolumn{3}{|c|}{$3 \% \mathrm{HCT}$} & \multicolumn{3}{|c|}{$50 \% \mathrm{HCT}$} \\
\hline & & ICT & SD & $\mathrm{FR}$ & ICT & SD & FR \\
\hline SJ44 & 10 & 4 & 4 & 4 & 4 & 4 & 4 \\
\hline \multirow{5}{*}{$\begin{array}{l}\text { Solomon } \\
\text { Islands }\end{array}$} & 1 & 4 & 4 & 4 & 4 & 4 & 4 \\
\hline & 0.1 & 4 & 3 & 2 & 3 & 3 & 1 \\
\hline & 0.01 & 1 & 1 & 0 & 0 & 1 & 0 \\
\hline & 0.001 & 1 & 0 & 0 & 0 & 0 & 0 \\
\hline & 0.0001 & 1 & 0 & 0 & 0 & 0 & 0 \\
\hline FCR3 & 16 & ND & 4 & 4 & ND & 4 & 4 \\
\hline \multirow[t]{5}{*}{ Gambia } & 1.6 & ND & 4 & 4 & ND & 4 & 4 \\
\hline & 0.16 & ND & 4 & 4 & ND & 4 & 4 \\
\hline & 0.016 & ND & 4 & 3 & ND & 3 & 2 \\
\hline & 0.0016 & ND & 2 & 1 & ND & 1 & 0 \\
\hline & 0.00016 & ND & 0 & 0 & ND & 0 & 0 \\
\hline GA3 & 17 & 4 & 4 & $\begin{array}{c}4 \\
\text { thin }\end{array}$ & 4 & 4 & $\begin{array}{c}4 \\
\text { thin }\end{array}$ \\
\hline \multirow[t]{5}{*}{ Thailand } & 1.7 & 4 & 4 & 4 & 4 & 4 & 4 \\
\hline & 0.17 & 4 & 4 & 4 & 4 & 4 & 4 \\
\hline & 0.017 & 3 & 3 & 3 & 2 & 3 & 3 \\
\hline & 0.0017 & 1 & 1 & 1 & 1 & 1 & 1 \\
\hline & 0.00017 & 0 & 0 & 0 & 0 & 0 & 0 \\
\hline S55 & 16 & ND & 4 & 4 & ND & 4 & 4 \\
\hline \multirow{5}{*}{$\begin{array}{l}\text { Solomon } \\
\text { Islands }\end{array}$} & 1.6 & ND & 4 & 4 & ND & 4 & 4 \\
\hline & 0.16 & ND & 4 & 4 & ND & 4 & 4 \\
\hline & 0.016 & ND & 2 & 2 & ND & 2 & 2 \\
\hline & 0.0016 & ND & 1 & 0 & ND & 0 & 0 \\
\hline & 0.00016 & $\mathrm{ND}$ & 0 & 0 & ND & 0 & 0 \\
\hline $7 G 8$ & 16 & ND & 4 & 4 & ND & 4 & 4 \\
\hline \multirow[t]{5}{*}{ Brazil } & 1.6 & ND & 4 & 4 & ND & 4 & 4 \\
\hline & 0.16 & ND & 4 & 4 & ND & 3 & 4 \\
\hline & 0.016 & ND & 2 & 2 & ND & 2 & 1 \\
\hline & 0.0016 & ND & 0 & 0 & ND & 0 & 0 \\
\hline & 0.00016 & ND & 0 & 0 & ND & 0 & 0 \\
\hline $7 \mathrm{G} 8$ & 25 & $\begin{array}{c}4 \\
\text { thin } \\
\end{array}$ & 3 & $\begin{array}{c}4 \\
\text { thin }\end{array}$ & $\begin{array}{l}4 \\
\text { thin }\end{array}$ & $\begin{array}{c}4 \\
\text { thin }\end{array}$ & $\begin{array}{c}4 \\
\text { thin }\end{array}$ \\
\hline \multirow[t]{5}{*}{ Brazil } & 2.5 & 4 & 4 & 4 & 4 & 4 & 4 \\
\hline & 0.25 & 4 & 4 & 4 & 4 & 4 & 4 \\
\hline & 0.025 & 4 & 4 & 4 & 4 & 2 & 3 \\
\hline & 0.0025 & 1 & 1 & 2 & 2 & 1 & 1 \\
\hline & 0.00025 & 1 & 0 & 0 & 0 & 0 & 0 \\
\hline
\end{tabular}

Note: ICT- ICT Malaria combo Cassette Test, ICT Diagnostics, South Africa; FRFirst Response Malaria Antigen pLDH/HRP2 Combo, Premier Medical

Corporation, Limited, India; SD- SD Malaria Antigen P.f, Standard Diagnostics, Korea. concentration and parasite density, and variation in the quality of RDT manufacture, could combine to result in a false negative test is conceivable, and in this circumstance could lead a clinician to miss a malaria diagnosis, as demonstrated in the case report quoted earlier[24].

\section{Conclusions}

These results and those previously published have a number of implications. Firstly, RDTs should not be viewed as quantitative tests. The plateau and fading effect may mislead the clinician to underestimate a potentially life-threatening hyperparasitaemia. Secondly, as recommended by WHO [1], patients with clinically severe illnesses in malaria-endemic areas should receive immediate treatment with anti-malarial drugs, and appropriate antibiotics, and referred for definitive diagnosis. Thirdly, the quality of manufacture of RDTs is likely to influence the likelihood of a prozone-like phenomenon resulting in false negative test results. Thus, further RDT development, and lot-release testing of RDTs, could usefully take this into account and include evaluation against high concentrations of antigen to ensure that false negative results will not occur at antigen concentrations that might be seen clinically.

\section{Acknowledgements}

This study was supported through the Malaria Rapid Diagnostic Tests Quality Assurance Project supported by the World Health Organization - Regional Office for the Western Pacific, and through funding to FIND from the Government of the Netherlands and the Bill and Melinda Gates Foundation. The authors have no conflict of interest. The opinions expressed herein are those of the authors and do not necessarily reflect those of the Australian Defence Force or any ADF extant policy.

\section{Author details}

'Department of Parasitology, Research Institute for Tropical Medicine, Alabang, Muntinlupa City, The Philippines. ${ }^{2}$ Drug Resistance and Diagnostics, Australian Army Malaria Institute, Brisbane, Australia. ${ }^{3}$ Department of Developmental Biology, The University of Texas Southwestern Medical Center, Dallas, TX, USA; formerly Department of Parasitology, Research Institute for Tropical Medicine, Alabang, Muntinlupa City, Philippines. ${ }^{4}$ Queensland Institute of Medical Research, University of Queensland, Brisbane, Australia. ${ }^{5}$ Foundation for Innovative New Diagnostics (FIND), Geneva, Switzerland; formerly World Health Organization - Regional Office for the Western Pacific, Manila, The Philippines.

\section{Authors' contributions}

JL, SA, VB performed and reported Trial 1. JB, QC, JM performed and reported Trial 2. DB coordinated the project and led manuscript writing. All authors contributed to and approved the manuscript.

\section{Competing interests}

The authors declare that they have no competing interests.

Received: 21 May 2011 Accepted: 29 September 2011 Published: 29 September 2011

\section{References}

1. WHO: Guidelines for the treatment of malaria. 2 edition. Geneva: World Health Organization; 2010. 
2. Thiam S, Thior M, Faye B, Ndiop M, Diouf ML, Diouf MB, Diallo I, Fall FB, Ndiaye $J$, Albertini A, Lee E, Jorgensen $P$, Gaye $O$, Bell D: Major reduction in anti-malarial drug consumption in Senegal after nation-wide introduction of malaria rapid diagnostic tests. PLoS One 2011, 6:e18419.

3. Murray CK, Gasser RA Jr, Magill AJ, Miller RS: Update on rapid diagnostic testing for malaria. Clin Microbiol Rev 2008, 21:97-110.

4. WHO-FIND-CDC-TDR: Malaria Rapid Diagnostic Test Performance: Results of WHO product testing of malaria RDTs: Round 2 (2009). Book Malaria Rapid Diagnostic Test Performance: Results of WHO product testing of malaria RDTs: Round 2 (2009) City: World Health Organization; 2010, (Editor ed. ^eds.).

5. Jelinek T, Grobusch MP, Schwenke S, Steidl S, von Sonnenburg F, Nothdurft HD, Klein E, Loscher T: Sensitivity and specificity of dipstick tests for rapid diagnosis of malaria in nonimmune travelers. J Clin Microbiol 1999, 37:721-723.

6. Moody A, Hunt-Cooke A, Gabbett E, Chiodini P: Performance of the OptiMAL malaria antigen capture dipstick for malaria diagnosis and treatment monitoring at the Hospital for Tropical Diseases, London. $\mathrm{Br} J$ Haematol 2000, 109:891-894.

7. Grobusch MP, Hanscheid T, Gobels K, Slevogt H, Zoller T, Rogler G, Teichmann D: Comparison of three antigen detection tests for diagnosis and follow-up of falciparum malaria in travellers returning to Berlin, Germany. Parasitol Res 2003, 89:354-357.

8. Farcas GA, Zhong KJ, Lovegrove FE, Graham CM, Kain KC: Evaluation of the Binax NOW ICT test versus polymerase chain reaction and microscopy for the detection of malaria in returned travelers. Am J Trop Med Hyg 2003, 69:589-592.

9. Mason DP, Kawamoto F, Lin K, Laoboonchai A, Wongsrichanalai C: A comparison of two rapid field immunochromatographic tests to expert microscopy in the diagnosis of malaria. Acta Trop 2002, 82:51-59.

10. Tjitra E, Suprianto S, Dyer M, Currie BJ, Anstey NM: Field evaluation of the ICT malaria P.f/P.v immunochromatographic test for detection of Plasmodium falciparum and Plasmodium vivax in patients with a presumptive clinical diagnosis of malaria in eastern Indonesia. J Clin Microbiol 1999, 37:2412-2417.

11. Gaye O, Diouf M, Dansokho EF, McLaughlin G, Diallo S: Diagnosis of Plasmodium falciparum malaria using ParaSight F, ICT malaria PF and malaria IgG CELISA assays. Parasite 1998, 5:189-192.

12. Desakorn V, Silamut K, Angus B, Sahassananda D, Chotivanich K, Suntharasamai $P$, Simpson J, White NJ: Semi-quantitative measurement of Plasmodium falciparum antigen PfHRP2 in blood and plasma. Trans $R$ Soc Trop Med Hyg 1997, 91:479-483.

13. Ashton RA, Kefyalew T, Tesfaye G, Counihan H, Yadeta D, Cundill B, Reithinger R, Kolaczinski JH: Performance of three multi-species rapid diagnostic tests for diagnosis of Plasmodium falciparum and Plasmodium vivax malaria in Oromia Regional State, Ethiopia. Malar J 2010, 9:297.

14. Huong NM, Davis TM, Hewitt S, Huong NV, Uyen TT, Nhan DH, Cong le D: Comparison of three antigen detection methods for diagnosis and therapeutic monitoring of malaria: a field study from southern Vietnam. Trop Med Int Health 2002, 7:304-308.

15. Forney JR, Wongsrichanalai C, Magill AJ, Craig LG, Sirichaisinthop J, Bautista CT, Miller RS, Ockenhouse CF, Kester KE, Aronson NE, Andersen EM, Quino-Ascurra HA, Vidal C, Moran KA, Murray CK, DeWitt CC, Heppner DG, Kain KC, Ballou WR, Gasser RA Jr: Devices for rapid diagnosis of malaria: evaluation of prototype assays that detect Plasmodium falciparum histidine-rich protein 2 and a Plasmodium vivax-specific antigen. J Clin Microbiol 2003, 41:2358-2366.

16. Quintana M, Piper R, Boling HL, Makler M, Sherman C, Gill E, Fernandez E, Martin S: Malaria diagnosis by dipstick assay in a Honduran population with coendemic Plasmodium falciparum and Plasmodium vivax.. Am J Trop Med Hyg 1998, 59:868-871.

17. Wongsrichanalai C, Chuanak N, Tulyayon S, Thanoosingha N, Laoboonchai A, Thimasarn K, Brewer TG, Heppner DG: Comparison of a rapid field immunochromatographic test to expert microscopy for the detection of Plasmodium falciparum asexual parasitemia in Thailand. Acta Trop 1999, 73:263-273.

18. Forney JR, Magill AJ, Wongsrichanalai C, Sirichaisinthop J, Bautista CT, Heppner DG, Miller RS, Ockenhouse CF, Gubanov A, Shafer R, DeWitt CC, Quino-Ascurra HA, Kester KE, Kain KC, Walsh DS, Ballou WR, Gasser RA Jr: Malaria rapid diagnostic devices: performance characteristics of the
ParaSight $\mathrm{F}$ device determined in a multisite field study. J Clin Microbiol 2001, 39:2884-2890.

19. Iqbal J, Khalid N, Hira PR: Comparison of two commercial assays with expert microscopy for confirmation of symptomatically diagnosed malaria. J Clin Microbiol 2002, 40:4675-4678.

20. Beadle C, Long GW, Weiss WR, McElroy PD, Maret SM, Oloo AJ, Hoffman SL: Diagnosis of malaria by detection of Plasmodium falciparum HRP-2 antigen with a rapid dipstick antigen-capture assay. Lancet 1994, 343:564-568.

21. Gamboa D, Ho MF, Bendezu J, Torres K, Chiodini PL, Barnwell JW, Incardona S, Perkins M, Bell D, McCarthy J, Cheng Q: A large proportion of P. falciparum isolates in the Amazon region of Peru lack pfhrp2 and pfhrp3: implications for malaria rapid diagnostic tests. PLOS One 2010, 5: e8091.

22. Baker J, McCarthy J, Gatton M, Kyle DE, Belizario V, Luchavez J, Bell D, Cheng Q, Baker DA: Genetic diversity of Plasmodium falciparum histidinerich protein 2 (PfHRP2) and its effect on the performance of PfHRP2based rapid diagnostic tests. J Infect Dis 2005, 192:870-877.

23. Lee N, Baker J, Andrews KT, Gatton ML, Bell D, Cheng Q, McCarthy J: Effect of sequence variation in Plasmodium falciparum histidine- rich protein 2 on binding of specific monoclonal antibodies: Implications for rapid diagnostic tests for malaria. J Clin Microbiol 2006, 44:2773-2778.

24. Gillet P, Mori M, Van Esbroeck M, Van den Ende J, Jacobs J: Assessment of the prozone effect in malaria rapid diagnostic tests. Malar J 2009, 8:271.

25. Traore I, Koita O, Duombo O, Kassambara L, Ouattara A, Diakite M, Sagara I, Diallo M, Krogstadt DJ: Field studies of the ParaSight $\mathrm{F}$ test in a malariaendemic area: Cost, feasibility, sensitivity, specificity, predictive value and deletion of the HRP2 gene among wild-type Plasmodium falciparum in Mali. Program and Abstracts of the 46th Annual Meeting of the American Society of Tropical Medicine and Hygiene; 1997; Lake Buena Vista, Florida 1997, 272, American Journal of Tropical Medicine and Hygiene.

26. WHO: Malaria rapid diagnosis: making it work. Book Malaria Rapid Diagnosis: Making it Work. Meeting report 20-23 January 2003 City: World Health Organization; 2003, Meeting report 20-23 January 2003. (Editor ed. ^eds.) .

27. Butch AW: Dilution protocols for detection of hook effects/prozone phenomenon. Clin Chem 2000, 46:1719-1721.

28. Pujol FH, Rodriguez I, Devesa M, Rangel-Aldao R, Liprandi F: A double sandwich monoclonal enzyme immunoassay for detection of hepatitis $B$ surface antigen. J Immunoassay 1993, 14:21-31.

29. el-Zaatari MM, Martens MG, Anderson GD: Incidence of the prozone phenomenon in syphilis serology. Obstet Gynecol 1994, 84:609-612.

30. Sato NS, de Melo CS, Zerbini LC, Silveira EP, Fagundes L, Ueda M: Assessment of the rapid test based on an immunochromatography technique for detecting anti-Treponema pallidum antibodies. Rev Inst Med Trop Sao Paulo 2003, 45:319-322.

31. Jurado RL, Campbell J, Martin PD: Prozone phenomenon in secondary syphilis. Has its time arrived? Arch Intern Med 1993, 153:2496-2498.

32. Pang YP, Rajesh H, Tan LK: Molar pregnancy with false negative urine hCG: the hook effect. Singapore Med J 2010, 51:e58-61.

33. Talamo G, Castellani W, Dolloff NG: Prozone effect of serum IgE levels in a case of plasma cell leukemia. J Hematol Oncol 2010, 3:32.

34. Papik K, Molnar B, Fedorcsak P, Schaefer R, Lang F, Sreter L, Feher J, Tulassay Z: Automated prozone effect detection in ferritin homogeneous immunoassays using neural network classifiers. Clin Chem Lab Med 1999, 37:471-476.

35. Frieze TW, Mong DP, Koops MK: "Hook effect" in prolactinomas: case report and review of literature. Endocr Pract 2002, 8:296-303.

36. WHO/TDR/FIND: Characteristics of evaluation panel used for Round 1 of WHO malaria RDT product testing at U.S. CDC, 2008. Book Characteristics of evaluation panel used for Round 1 of WHO malaria RDT product testing at US CDC, 2008 City: WHO - Regional Office for the Western Pacific; 2009.

37. WHO-TDR-FIND: Methods Manual for Laboratory Quality Control Testing of Malaria Rapid Diagnostic Tests, Version Six Geneva: World Health Organization; 2010

38. WHO/FIND/CDC: Methods manual for product testing of malaria rapid diagnostic tests (version 1) Manila: World Health Organization - Regional Office for the Western Pacific; 2008.

39. Chiodini PL, Bowers K, Jorgensen P, Barnwell JW, Grady KK, Luchavez J, Moody AH, Cenizal A, Bell D: The heat stability of Plasmodium lactate 
dehydrogenase-based and histidine-rich protein 2-based malaria rapid diagnostic tests. Trans R Soc Trop Med Hyg 2007, 101:331-337.

40. Lambros C, Vanderberg JP: Synchronization of Plasmodium falciparum erythrocytic stages in culture. J Parasitol 1979, 65:418-420.

doi:10.1186/1475-2875-10-286

Cite this article as: Luchavez et al.: Laboratory demonstration of a prozone-like effect in HRP2-detecting malaria rapid diagnostic tests: implications for clinical management. Malaria Journal 2011 10:286.

Submit your next manuscript to BioMed Central and take full advantage of:

- Convenient online submission

- Thorough peer review

- No space constraints or color figure charges

- Immediate publication on acceptance

- Inclusion in PubMed, CAS, Scopus and Google Scholar

- Research which is freely available for redistribution

Submit your manuscript at www.biomedcentral.com/submit 